\title{
IAMJ
}

INTERNATIONAL

AYURVEDIC

MEDICAL JOURNAL

\section{A CLINICAL STUDY TO EVALUATE RUKSHANA PURVAKA VIRECHANA KARMA IN STHOULYA WITH SPECIAL REFERENCE TO OBESITY}

\author{
Nimya K K ${ }^{1}$ Rajalaxmi M.G. $^{2}$ \\ ${ }^{1}$ MD Scholar, ${ }^{2}$ Associate Professor, \\ Department of P.G. studies in Panchakarma, Shree Dharmasthala Manjunatheshwara College of Ayurveda, Udupi, \\ Karnataka, India
}

\section{Corresponding Author: nimyakk63@gmail.com}

\section{https://doi.org/10.46607/iamj02p5062021}

(Published online: September 2021)

Open Access

(C) International Ayurvedic Medical Journal, India 2021

Article Received: 21/08/2021 - Peer Reviewed: 10/09/2021 - Accepted for Publication: 11/09/2021

\section{Check for updates}

\section{ABSTRACT}

Sthoulya/Obesity is a medical condition in which excess body fat has accumulated to the extent that it may hurt the health and it is one of the most neglected public health issues. Sthoulya is most caused by Ati Ahara Sevana, Avyayama and Beejadosha. Sthoulya has been explained in Charaka Samhita Sutra Sthana under $21^{\text {st }}$ chapter by name Astou Ninditiya Purusha as Santarpana Nimittaja Vikara ${ }^{l}$, Bahudoshavastha Vyadhi ${ }^{2}$ and included under Sleshmaja Nanatmaja Vikara. In Sushruta Samhitha also Sthoulya is narrated as rasa Nimittaja Vyadhi and considered Meda vitiation as the causative factor for the manifestation. He also described Sthoulya as the physical condition of the body caused due to Dhatvagni Mandya. Acharya Charaka has also explained Swastha Purusha Laxana in terms of Sama Mamsa, Sama Pramana, Sama Samhanana and having Dridha Indriya. But Sthula Purusha is devoid of above-said qualities. Obesity contributes to many morbidities in the population, and it is known as a causative or precipitating factor for various killer ailments like hypertension, diabetes, prostate problems, breast and colon cancers, respiratory problems, joint disorders, stroke, heart diseases like IHD/CAD etc.

Keywords: Obesity, Sthoulya, Virechana

\section{INTRODUCTION}

It is universally accepted that good mental and physical health plays a major role in human development.
According to the theories of Ayurveda, good health is based on the balanced state of dosha, dhatu, agni and 
mala. ${ }^{3}$ Sushruta opines that madhyama shareera is the best, atisthula and atikrisha shareera always may have some problems. In Ayurveda, sthoulya vyadhi is explained in santarpana janya vyadhi and atisthula purusha is considered as one of the ashto nindita purusha. ${ }^{4} \mathrm{WHO}$ (world health organization) defines good health as the state of complete physical, mental and social wellbeing and not merely an absence of disease or infirmity. ${ }^{5}$ Man has become more and more physically inactive due to the evolution of civilization. The dinacharya and ritu charya which is mentioned in Ayurvedic classics are ignored. Because of the modern lifestyle, human beings are unknowingly inviting a number of diseases. Sthoulya is one such disease that disturbs the mental, physical and social health of an individual. High blood pressure, stroke, diabetic mellitus, osteo-arthritis, cancers, coronary heart disease (CHD) etc. are the major risk factors for obesity $^{6}$. A metabolic syndrome is a group of risk factors that raises the risk for cardiovascular diseases and health issues. In obesity, osteo-arthritis is a common joint disorder. People who are having obesity are at increased risk of having gallstones. In women, sthoulya may cause menstrual problems and infertility. In children, there is a risk of disability in adulthood or even it may lead to premature death. Sthoulya is a santharpanotta vyadhi and the management for such disease is said to be apatarpana ${ }^{7}$ and there is an explanation of chikitsa sutra in the classics which explains guru cha atarpana. Since apatarpana is the line of management of sthoulya which can be achieved through panchakarma procedures like vamana, virechana, lekhana and rukshana basti etc. Virechana is one of the shodhana procedures, which expels morbid dosha and helps to maintain health of an individual. Before snehapana for those individuals who are presenting with mamsala, medura, bhuri shleshma and with vishamagni, who is habituated to consume sneha also and who are considered to be fit for snehana therapy should undergo rukshana prior to snehana. If they follow the rukshana therapy before snehapana, then no complications are manifested. If pre-operative procedures are followed, then complications of snehana can be easily avoided. The sneha used for the therapy will not undergo sathmya and will be capable of disassembling the mala for elimination. In the present study, for the purpose of virechana the yoga selected was vyoshadi modaka. To assess its efficacy in the management of sthouly w.s.r to obesity a clinical study has been undertaken under the title "A clinical study to evaluate rukshana purvaka virechana karma in sthoulya with special reference to obesity

\section{OBJECTIVES OF THE STUDY}

- Conceptual study of rukshana upakrama, virechana, sthoulya and obesity.

- To evaluate the effect of rukshana purvaka virechana karma in the management of sthoulya.

\section{Patients and methods}

\section{Source of data}

Drug source: The medicines (Musta churna ${ }^{8} /$ Triphala kashaya $a^{9} /$ Triphaladya taila ${ }^{10} /$ Mudga yusha/Murchitha taila /Dashamoola kwatha choorna/Vyoshadi Modaka ${ }^{11}$ ) used in the study was prepared in Sri Dharmasthala Majunadeswara Ayurveda pharmacy, Udupi.

\section{- Patient source:}

Minimum of 30 patients diagnosed as sthoulya fulfilling the study criteria were taken from Sri Dharmasthala Manjunadeswara Ayurveda Hospital, Kuthpady, Udupi.

\section{Method of collection of data \\ Inclusion criteria}

$\checkmark$ Patients aged between 16 to 60 years.

$\checkmark$ Patients fulfilling the diagnostic criteria.

$\checkmark$ Patients Yogya for Virechana and Rukshana Karma.

$\checkmark \quad \operatorname{BMI}(\mathrm{Kg} / \mathrm{m} 2)-25$ to 39.9

\section{Exclusion criteria}

- Patients with any systemic disorders which interfere with the course of treatment

- Obesity due to endocrinal abnormalities

- Patients with Hypertension and Diabetes mellitus

- Subjects who are not fit for virechana karma

\section{Investigations}

- Haematological tests such as Hb\%, TC, DC, ESR

- Urine analysis 
- Lipid profile-Total cholesterol, LDL, HDL, VLDL, and Triglycerides

- Thyroid profile if necessary.
Study Design: It is an open clinical study with pretest and post-test design wherein a minimum of 30 patients diagnosed as sthoulya of either gender were selected based on diagnostic and inclusion criteria.

Table 1: Intervention

Purva Karma

\begin{tabular}{|l|l|l|l|}
\hline karma & medicine & dose & days \\
\hline Pachana \& Deepana & $\begin{array}{l}\text { Musta Churna with Su- } \\
\text { khoshna Jala }\end{array}$ & $\begin{array}{l}\text { Till getting No } \\
\text { Lakshana }\end{array}$ \\
\hline Abhyantara Snehapana & Triphaladya Taila & $\begin{array}{l}\text { Minimum 50 ml maximum ill } \\
\text { Samyak Snehapana Lakshanas }\end{array}$ & \begin{tabular}{l}
$3-7$ days \\
\hline Sarvanga Snehana (abhyanga)
\end{tabular} \\
\hline Bashpa Sweda & Murchita Tila Taila & & 4 days \\
\hline
\end{tabular}

Pradhana Karma

\begin{tabular}{|l|l|l|l|}
\hline karma & medicine & dose & days \\
\hline Virechana & Vyoshadi modaka & 30 To $55 \mathrm{Grms}$ & On $4^{\text {th }}$ day of sarvanga snehana and bashpa sweda \\
\hline
\end{tabular}

\section{Paschat Karma}

Samsarjana karma advised according to the shudhi lakshana

\section{Assessment criteria}

Symptoms before the treatment, after the treatment and after the follow up were assessed based on the detailed proforma adopting standard method of scoring of subjective and objective parameters which will be analysed statistically.

\section{Subjective parameters}

- Lakshanas of sthoulya

1. Chala-Stana, Udara, Sphik

2. Kshuda Adhikya.

3. Nidradikya

4. Daurgandya

5. Swedadhikya
- Laingiki features in the form of Samyak Yoga, Atiyoga \& Ayoga features of Virechana Karma.

- Aantiki features of Virechana Karma.

- Vegiki features of Virechana Karma

\section{Objective parameters}

* Bodyweight

* BMI (kg/m2)

* Anthtrapometric features (measuring skinfold thickness by using slide callipers), Triceps, Biceps, Subscapular, Abdomen and thigh.

The measurement was taken at various levels viz

* Chest

* Waist

* hip

* Waist hip ratio

* Measurement was taken before treatment, after treatment, and during follow up

\section{Observations}

\begin{tabular}{|l|l|l|l|l|l|l|}
\hline $\begin{array}{l}\text { S1 } \\
\text { no }\end{array}$ & Parameters & $\begin{array}{l}\text { Before treat- } \\
\text { ment (Mean) }\end{array}$ & $\begin{array}{l}\text { After rukshana } \\
\text { (Mean) }\end{array}$ & $\begin{array}{l}\text { After snehapana } \\
\text { (Mean) }\end{array}$ & $\begin{array}{l}\text { After virechana } \\
\text { (Mean) }\end{array}$ & $\begin{array}{l}\text { After follow up } \\
\text { (Mean) }\end{array}$ \\
\hline 1 & BMI & 31.0033 & 29.8967 & 29.8967 & 29.8967 & 29.8967 \\
\hline 2 & Weight in Kg & 80.75 & 77.8200 & 77.8200 & 77.8200 & 77.8200 \\
\hline 3 & Chest & 91.961 & 90.7000 & 90.7000 & 90.7000 & 90.7000 \\
\hline 4 & Waist & 94.5 & 92.3933 & 92.3933 & 92.3933 & 92.3933 \\
\hline 5 & Hip & 96.3133 & 94.6600 & 94.6600 & 94.6600 & 94.6600 \\
\hline 6 & Waist/hip ratio & .9737 & ---- & ---- & .9640 & .9650 \\
\hline
\end{tabular}




\section{Observation on skinfold thickness}

\begin{tabular}{|l|l|l|l|l|}
\hline S1 no & Parameters & Before treatment (Mean) & After Virechana (Mean) & After following up (Mean) \\
\hline 1 & Biceps & 30.0000 & 28.6067 & 28.6067 \\
\hline 2 & Triceps & 26.3333 & 25.6000 & 25.6000 \\
\hline 3 & Supra iliac & 33.2667 & 31.0667 & 31.0667 \\
\hline 4 & Subscapular & 27.1333 & 25.4000 & 25.4000 \\
\hline
\end{tabular}

\section{Observations on lipid parameters}

\begin{tabular}{|l|l|l|l|}
\hline Sl no & Parameters & Before treatment (Mean) & After follow up (Mean) \\
\hline 1 & Total cholesterol & 173.1667 & 144.6333 \\
\hline 2 & Triglycerides & 91.8000 & 76.6000 \\
\hline 3 & HDL & 48.3667 & 51.8000 \\
\hline 5 & LDL & 95.2667 & 87.5333 \\
\hline
\end{tabular}

\section{Result}

\begin{tabular}{|l|l|l|l|l|l|l|l|}
\hline \multirow{2}{*}{ Parameters } & Mean & & S.D of diff. & S.E & Paired t statistics & P-value (one-tailed) \\
\cline { 2 - 7 } & Before & after & Diff & & & & \\
\hline BMI & 31.0033 & 29.8967 & $\mathbf{1 . 1 0 6 6}$ & 3.11509 & .54884 & 18.784 & .000 \\
\hline Weight in Kg & 80.75 & 77.8200 & $\mathbf{2 . 9 3}$ & 10.94751 & 1.99873 & 14.539 & .000 \\
\hline Waist & 91.961 & 90.7000 & $\mathbf{1 . 2 6 1}$ & 14.08420 & 2.57141 & 7.798 & .000 \\
\hline Hip & 94.5 & 92.3933 & $\mathbf{2 . 1 0 6 7}$ & 17.40001 & 3.17679 & 10.352 & .000 \\
\hline Waist/hip ratio & 96.3133 & 94.6600 & $\mathbf{1 . 6 5 3 3}$ & 13.35401 & 2.43810 & 8.326 & .000 \\
\hline Biceps & .9737 & .9650 & $\mathbf{0 . 0 0 8 7}$ & .07300 & .01333 & 1.733 & 0.94 \\
\hline Triceps & 30.0000 & 28.6067 & $\mathbf{1 . 3 9 3 3}$ & 5.68946 & 1.03875 & 4.328 & .000 \\
\hline Supra iliac & 26.3333 & 25.4000 & $\mathbf{0 . 7 3 3 3}$ & 8.17200 & 1.49200 & 1.957 & .000 \\
\hline Subscapular & 33.2667 & 31.0667 & $\mathbf{2 . 2}$ & 4.94801 & .90338 & .571 & .000 \\
\hline Total cholesterol & 27.1333 & 25.4000 & $\mathbf{1 . 7 3 3 3}$ & 1.84951 & .33767 & 1.185 & .000 \\
\hline Triglycerides & 91.8000 & 76.6000 & $\mathbf{1 5 . 2}$ & 23.17341 & 4.23087 & 17.285 & .000 \\
\hline HDL & 48.3667 & 51.8000 & $\mathbf{- 3 . 4 3 3 3}$ & 6.52528 & 1.19135 & -27.99 & .000 \\
\hline LDL & 95.2667 & 87.5333 & $\mathbf{7 . 7 3 3 4}$ & 6.51647 & 1.18974 & 19.569 & .000 \\
\hline VLDL & 18.7000 & 15.1333 & $\mathbf{3 . 5 6 6 7}$ & 3.92809 & .71717 & 23.905 & .000 \\
\hline & & & & & & & .000 \\
\hline
\end{tabular}




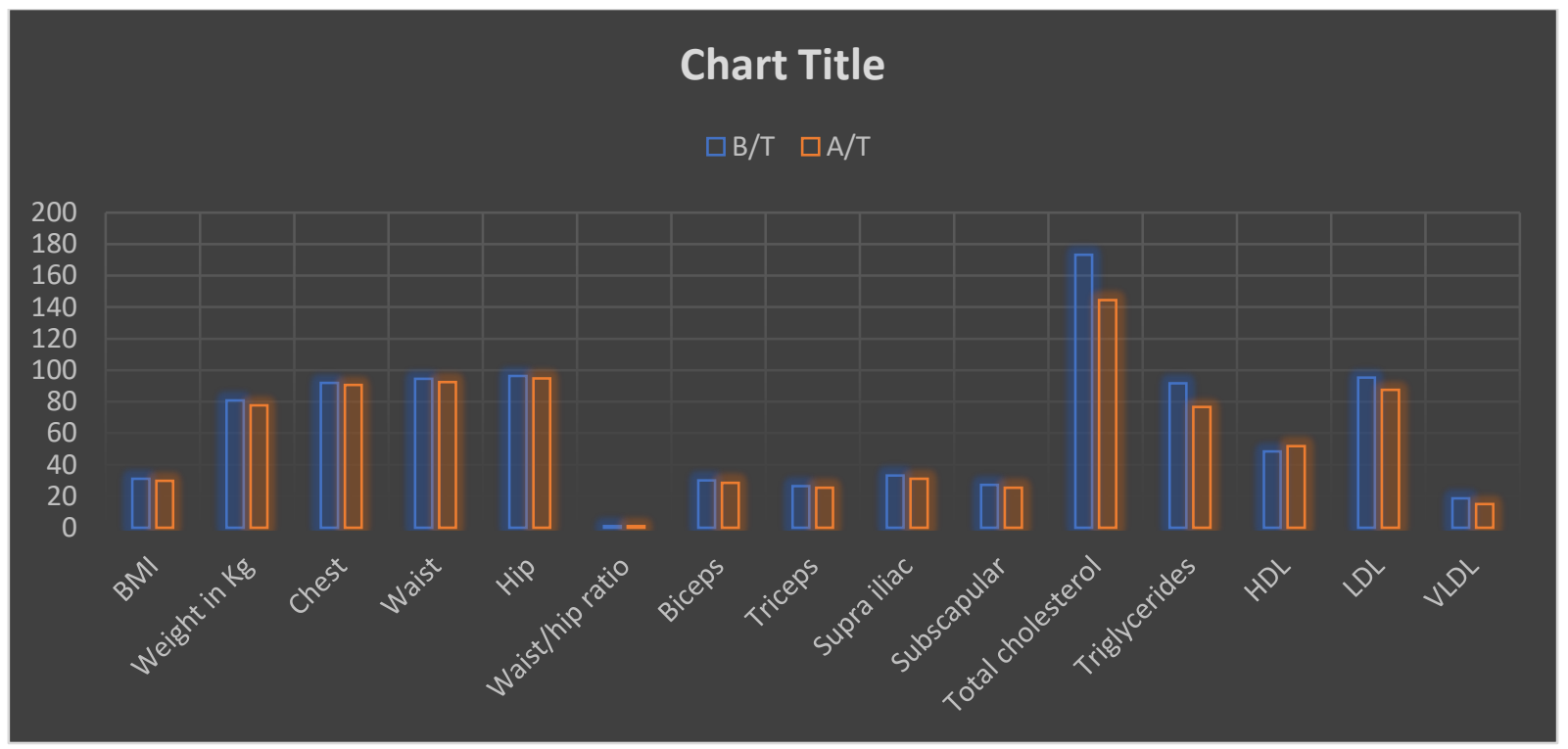

\section{DISCUSSION}

Rukshana is included under shadvidhopakrama. ${ }^{12}$ this upakrama are necessary to treat at different stages of the same disease. This upakrama are intended towards tridosha, even though there are different permutations and combinations of the dosha. Shadvidhopakrama which is explained by Charaka can be categorized and can be included under dwividhopakrama. One such upakrama is Rukshan which can be included under langhana upakrama. Hence the overall effect of rukshana is ultimately resulting in langhana only. Those drugs which possess the properties like ruksha, laghu, khara, tikshna, ushna, sthira, picchila, is considered to be under rukshana ${ }^{13}$. This can be achieved through Bahya and abhyantara prayoga. Bahya prayoga in the form of udwartana, vyayama etc. Whereas abhyantara prayoga can be achieved in the form of ahara as well as aushadha. In the form of ahara, we can plan yava yavagu, kulatha as well as takra pana. ${ }^{14}$ In the form of aushadha, triphala qwatha orally is administered for nitya virechana during apana kala. Such a practice can help in eliminating excess kleda in the body resulting in the manifestation of rukshana with the ultimate effect as langhana. ${ }^{15}$ Hence such a modality which can do anulomana and also kleda nirharana can be very well explained to attain rukshana in due course of time. The same principle is practiced prior to the onset of snehapana in those individuals who are having mamsala, medura, bhuri shlema and vishamagni. ${ }^{16}$ Once they attain rukshana then it is possible for us to start snehapana. This state of the patient is known as sneha asathmya avastha which is necessary to perform mala udeerana. ${ }^{17}$ (a.h.su.16/39) Rukshana was administered with triphala kashaya in the dose of $100 \mathrm{ml}$ bd. The kashaya was administered at $6.30 \mathrm{am}$ and $4 \mathrm{pm}$. The purpose of administering triphala kashaya was to reduce the kledata in the body and also to reduce the excess fat which is prevailing in the patients of sthoulya. As triphala is considered to be the best drug of choice for reducing kleda, kapha and medas in the body, it was found that those who had consumed triphala kashaya were depleting their body weight due to excess fluid loss. There was an observation during rukshana treatment that approximately $80 \%$ of the patients were complaining vomiting, which may be due to presence of excess kleda in amashaya which is contributing towards hrillasa, thereby for some of the individuals, it was ended up in the form of chardi.In the present study, musta churna was selected for deepanapachana. Amapachana is said to be mandatory before undergoing the process of shodhana. Musta has the properties such as katu, tikta, kashaya rasa, sheeta veerya and it alleviates kapha and pitta dosha. The data of 30 patients for the attainment of samyak 
snigdha lakshana depicts that a minimum of 3 days and a maximum of 4 days were required.The mean total amount of taila which was required for the attainment of samyak snigdha lakshana was $460 \mathrm{ml}$. On the $1^{\text {st }}$ day, the average amount of taila was $50 \mathrm{ml}, 2^{\text {nd }}$ day $85 \mathrm{ml}, 3^{\text {rd }}$ day $152 \mathrm{ml}$ and $4^{\text {th }}$ day $194 \mathrm{ml}$. Out of 30 patients maximum of $53.3 \%$ (16) of the patients consumed in between $400-500 \mathrm{ml}, 40 \%$ (12) of the patients consumed in between $500-600 \mathrm{ml}$ and $3.3 \%$ (1) i.e. one patient each required in between $300-400 \mathrm{ml}$ and 700-800 $\mathrm{ml}$. The present study shows that out of 30 patients all the patients got sneha udgara. 93.33\% of patients were having arati and klama, $86.66 \%$ patients were observed having shiroruja, $83.33 \%$ patients were observed having trishna, $53.33 \%$ patients were observed with angasada, $33.33 \%$ patients observed with bhrama and $20 \%$ patients were observed with lalasrava. In present this study, jeerna lakshana were observed in each patient every day during snehapana. Ugdara shuddhi and vatanulomana was obtained in all the patients. 24(80\%) patients got trishna pravruti. $23(76.6 \%)$ patient got kshut, and $17(56.66 \%)$ patients got sharira laghuta.This includes vatanulomana, snehodwega, adhastat sneha darshana, twak snigdhata. These all were observed in $100 \%$ of patients. Klama was observed in $90 \%$ of the patients. $80 \%$ got gatra mardavata, $60 \%$ got asamhata varchas, $56.66 \%$ got agni deepti, $53.33 \%$ got anga laghavata, and $23.33 \%$ got snigdha varcha. If the patient had a maximum reduction of the weight during the rukshana and snehapana, such patients had experienced more of klama. 6 patients vomited during the last day of snehapana i.e. on the $4^{\text {th }}$ day of snehapana. Vomiting was observed due to the large quantity of taila also there was repeated belching and distaste appearing in the patient resulted in a vomiting sensation. Only one patient got cramping nature of abdominal pain during the snehapana. Other than vomiting and abdominal pain no other complications were observed during snehapana. After the attainment of samyak snigdha lakshana, three days of bahya snehana and swedana was performed and on the $4^{\text {th }}$ day after bashpa sweda, virechana was administered. The majority of the patients obtained swinna laxana within 20 minutes. In the present study, out of 30 patients, all the patients exhibited samyak swinna lakshana. On the day of virechana karma after performing bashpa sweda, virechana drug by the name vyoshadi modaka was administered on empty stomach with hot water as anupana. The minimum dose of vyoshadi modaka required for the virechana karma was $35 \mathrm{gm}$ and the maximum dose required was 55 gm amongst 30 patients. Out of 30 patients, 21 patients got vomiting during virechana karma. Analysis of the cause of urdhwa gati of the dosha after administering virechana oushadha. One of the reasons attributed to the cause of vomiting was the presence of utklista kapha in the amashaya. The classics highlight the importance of the absence of kapha in the amashaya which is a pre-requisite condition for the proper virechana. Even the drug which is ushna also having an association of vyavayi and vikasi guna will result in the irritation of amashaya and hence urdhwa gati of the dosha was observed in the patient in the form of chardi. One of the patients had a feature of urdhwa maruta laxana, and once anulomana started in the form of adhopravritti, then vomiting was stopped. Out of 30 patients, maximum of $25(83.3 \%)$ patients had madhyama shuddhi and 5(16.7\%) patients had pravara shuddhi. This parameter will help us to plan samsarjana krama accordingly. Urdwa pravritti was observed in 21 patients and it was because of Vyoshadi modaka as a virechana dravya containing ushna, tikshna, vyavayi, vikasi medicines when administered in the presence of utklishta kapha or utklishta kapha in amashaya, results in vomiting. This suggests that the absence of kapha in the amashaya should be the state of amashaya which is desired for the purpose of virechana karma. Upastitha kapha tends to produce irritation in the stomach after contact with the medicine. Hence it is evident that vyoshadi modaka has kapha chedana property and hence it is best advised to avoid in upastitha kapha avastha. Another reason which is attributed to the repeated vomiting was the presence of savasheshoudhatwa. Virechana process will start when there is pachyamanavastha. But due to the remnant medicine which had not entered into such 
avastha will remain in the amashaya and results in the manifestation of delayed vomiting in the patient. The signs and symptoms of sthoulya roga depict that there is a predominance of kapha dosha which is contributing to a great extent and secondly there is an involvement of vata dosha also. Medodushti in kaphaja vyadhi results in the disease medoroga. Medoroga is a clinical condition where bahudosha avastha is already presented and hence this condition demands shodhana chikitsa. Virechana helps to eliminate a huge quantity of dravamsha (kleda) from the body and thereby helps to decrease the weight. Kleda represents udaka tatwa in the body. Kledakaraka guna is present in sneha dravya. kledane snigdha: ${ }^{18}$ Hence those drugs which possess the properties of snehana can induce more kledata in the body. Kledayukta dravya will have ardri bhava. There are innumerable kleda pradhana vyadhi explained in the classics. For all those vyadhi, initially, rukshana is necessary since they are all said to be unfit for snehapana. Hence prior to the snehapana, it is necessary to start with rukshana for the purpose of kleda shoshana. Those diseases which are highlighted for the purpose of rukshana are abhishyanda roga, mahadoshaja vyadhi, marmashrita vyadhi, urustambha. Kleda can even be found in the diseases such as shotha, prameha, sthoulya, kushta (kapha and pitta pradhana) udara, pidaka, kamala, pandu, shleepada vyadhi. The presence of kleda in the body may lead to different symptoms such as kandu, srava and vaivarnya in the case of kushta vyadhi. Pendulous abdomen, flabby skin and oedema in different areas of the body may signify the presence of kleda which is associated with mamsa and medo dhatu. Hence to combat the kledata in the body as well as to attain shoshana, rukshana is indicated. Prashasta purusha laxana: The classics highlight the importance of maintaining a healthy and proportionate body. There is an explanation in the classics about sama mamsa pramana, sama samhanana and shareera dridhata which is praised to be maintained for the purpose to stay healthy always. If such proportion is disturbed then it is included under nindita purusha narrated in astou ninditeeya adhyaya of charaka sutrasthana.Sthoulya is considered to be having bahudoshavastha due to morbid kapha dosha and mamsa medo dhatu. As per the classifications of the vyadhi, it is included under the santarpanotta vyadhi. The root cause for its manifestation is highly attributed to a mismatch between energy intake and expenditure. Such imbalance is identified as sthoulya which is shodhana sadhya vyadhi. Owing to the involvement of kapha pradhana tridosha associated with mamsa and medo dhatu which is abaddha in nature, can present with huge quantity of kleda in the body. Such kleda can be observed in the patients of sthoulya in the form of puffiness of the face and neck region, subcutaneous oedema in the forearm region and also the presence of pedal edema. These are included under kleda in the body. Classics highlights the treatment principles of santarpanotta vyadhi in terms of apatarpana. Since it is a bahudoshavastha, under apatarpana, doshavasechana is the ideal line of treatment. Even though it is a kapha pradhana vyadhi with more of kledata, can be handled through rukshana purvaka shodhana. When two of the shodhana like vamana and virechana is compared, there will be huge elimination of the dosha observed in virechana which is evidenced through one of the assessment parameters such as maniki criteria. After understanding the gravity of the problem along with the pros and cons of the virechana, rukshana was considered as the preliminary pre-requisite treatment prior to virechana and the study was aimed towards attaining the madhyama shareera and also to impart the quality of life. Different parameters were considered to monitor obesity such as BMI and allied tests which were considered to be supportive evidence to prove the aftereffect of the treatment. Amongst Panchakarma, in virechana there is excess loss of drava dhatu when compared to vamana as it is depicted in maniki criteria. Hence whenever there is the involvement of tridosha along with more of drava in mamsa and medo dhatu, the best method is to mobilize them through snehapana from shaka to koshta and can be eliminated through the nearest route in the form of virechana. 


\section{CONCLUSION}

The modern lifestyle has resulted in some metabolic diseases. One amongst them is considered obesity which is the result of an imbalance of calorie intake and its expenditure. Such a disease may be considered as the risk factor for numerous other diseases. To enumerate some are cardiovascular diseases, metabolic syndrome, insulin resistance, peripheral vascular diseases, dyslipidemia, diabetes mellitus. When such is the big list of diseases, one has to take care of one's own body by following dinacharya as per the respective ritu. If any injustice in following dinacharya may lead to the above-said diseases in due course of time. In this regard, obesity is considered to be the mother of all diseases. Every attempt has to be made to achieve sama pramana shareera (Proportionate body) which means neither it should be sthula nor it should be krisha. Only madhyama shareera is praised in classics. The present study is intended towards the attainment of madhyama shareera in those individuals who have possessed with sthoulya. There is a notion in the classics which says that karshya is said as shresta when compared to sthoulya as there will not be appropriate medicine to handle ati sthoulya. Panchakarma is helpful in attaining dosha and dhatu samyata. Hence an attempt is made to explore the concept of rukshana purvaka virechana in the management of sthoulya w.s.r. to obesity. All tridosha are involved in the manifestation of the disease sthoulya but the vitiation of kapha, mamsa and meda plays a very important role here. As a part of rukshana, triphala qwatha was administered twice daily in apana kala. This was sufficient to induce nitya virechana thereby kleda nirharana was the outcome. Hence after proper rukshana karma patients were getting apatarpana effect in terms of weight reduction. Hence as a part of rukshana karma, the majority of the patients were experiencing agni mandhya which was corrected with the help of musta churna. Those who were possessed with mamsala, medura, bhuri shleshamala and who is having vishamagni should undergo rukshana therapy before snehana to avoid complications of snehana. So that sneha used for the therapy will not be acclimatized and will be capable of disas- sembling the mala for elimination. The trial drug triphala in the form of qwatha acts as best kapha medohara and also it is kleda shoshaka and hence it was beneficial in reducing kapha, kleda and abaddha medas. For snehapana also the trial drug selected was triphaladi taila which is possessing the properties such as kapha pittahara. Hence drava dhatu can be mobilized through snehapana and brought to koshta, later through virechana dosha are excreted out of the body. In this regard, Virechana is said to be beneficial in sthoulya w.s.r. to obesity. Since obesity is considered to be the risk factor for many diseases, once there is a reduction of weight then automatically homeostasis of the body will be maintained. Only medo dhatu will be excessively nourished but further dhatu can't be nourished. Obesity can lead to a number of serious health problems, including heart diseases, diabetics, stroke etc so treating obesity will prevent such diseases. The sample size of the study was very minimum and hence a great conclusion can't be drawn based on the small sample but requires a large sample size to give a valuable opinion. Obesity is caused by the consumption of high-calorie diet particularly fat and sugar. Disfigurement caused due to obesity was the more concern prevailing in the society. This worry was being eradicated due to drastic weight reduction appreciated in few patients within a short span of time. The adverse effects arising out of obesity can be very well controlled. This way we can prevent the secondary onset of diseases. In classics, it was opined that karshyameva varam sthoulyam. Hence it is very difficult to reverse the condition if the patient has ati sthoulya avastha. Before that stage, itself management has to be done appropriately by following the principle of treatment of sthoulya. In the present study, since the weight reduction was 10 $\mathrm{kg}$ as maximum, the study had contributed a ray of hope in the society to take such principled treatment.

\section{REFERENCES}

1. Agnivesh "Charaka Samhita "Revised By Charaka and Dridhabala with the Ayurveda Deepika Commentary Of Chakrapanidatat, Reprint 2004, Choukambha Samskrit Samsthana, And Varanasai U.P.Pp-738, 122. 
2. Agnivesh "Charaka Samhita "Revised By Charaka and Dridhabala with the Ayurveda Deepika Commentary Of Chakrapanidatat, Reprint 2004, Choukambha Samskrit Samsthana, And Varanasai U.P.Pp-738, 122.

3. Acharya Susruta Samhita "Sushruta Samhita" With Nibandha Sangraha Commentary Of Dalhana And Tha Nyayachandrika Panchika Of Gayadasa On Nidana Sthana;6 Th Edition, 1997, Choukambha Orientalia Varanasi U.P; Pp-824;Page No 181.

4. Agnivesh "Charaka Samhita", Revised By Charaka And Dridhabala With The Ayurvedia Dipika Commentary Of Chakrapanidatta, Reprint 2004, Choukambha Samskrit Samsthana, And Varanasi U.P Pp-738; Page No:116

5. Https://Www. Who.Int

6. Occupational Lifestyle Diseases an Emergency Issue in Indian Journal of Occupational And Environmental Medicine, Mukesh Sharma And Pk Mujumdar,2009 December 13(3):109-112

7. Agnivesh "Charaka Samhita", Revised By Charaka And Dridhabala With The Ayurvedia Dipika Commentary Of Chakrapanidatta, Reprint 2004, Choukambha Samskrit Samsthana, And Varanasi U.P Pp-738; Page No:117

8. 8. Acharya Yadavji Trikamji, editor, ( $7^{\text {th }}$ ed.). commentary Ayurveda Dipika of Chakrapani Dutta on Charaka samhita of Agnivesha, Sutra Sthana; Yajna purusheeya Adhyaya: chapter 25, verse 40.Varanasi:Choukambha Sanskrit Sansthan,2009;pg 131

9. Mishra Sidhinanda Editor, Bhaishajya rathnavali shodadhikara of kaviraj govinda das sen 42 adhyaya verse 28 Varanasi: Choukambha surbharathi Prakashan,2011 page 767

10. Sri Ganga Sahaya Pandeya, editor (reprint). Commentary Vaidyotini of Sri Vaidya Shodala on Gada Nigraha, Medoroga Adhikara: chapter 31, verses 2224.Varanasi:Choukambha Sanskrit Sansthan, 2005;pg 693

11. Sri Ganga Sahaya Pandeya, editor (reprint). Commentary Vaidyotini of Sri Vaidya Shodala on Gada Nigraha, Virechana Adhikara: chapter 4, verse 20.Varanasi:Choukambha Sanskrit Sansthan, 2005;pg 884

12. Acharyajadavji Trikamji, Editor Ayurveda Deepika Commentary of Chakrapanidatta on Charaka Samhita of Agnivesha, Sutra Sthana; Langhana Brahmaniya Adhyaya: Chapter 22, Verses 14. Varanasi: Chaukamba, Krishnadas Academy,2010;120
13. Acharyajadavji Trikamji, Editor Ayurveda Deepika Commentary of Chakrapanidatta on Charaka Samhita of Agnivesha, Sutra Sthana; Langhana Brahmaniya Adhyaya: Chapter 22, Verses 14. Varanasi: Chaukamba, Krishnadas Academy,2010;120

14. Acharyajadavji Trikamji, Editor Ayurveda Deepika Commentary of Chakrapanidatta on Charaka Samhita of Agnivesha, Sutra Sthana; Langhana Brahmaniya Adhyaya: Chapter 22, Verses 14. Varanasi: Chaukamba, Krishnadas Academy, 2010;121

15. Bhishagacharya Pandit Hari Sadashiva Shastri Paradakara, Editor. Sarvangasundara Commentary of Aruna Datta And Ayurveda Rasayana Commentary Of Hemadri On Ashtanga Hridaya Of Acharya Vagbhata, Sutrastana Ayushkameeya Adhyaya: Chapter 1 Verses 18. Varanasi: Chaukambha Sanskrit Sanstan:2016;12

16. .Bhishagacharya Pandit Hari Sadashiva Shastri Paradakara, Editor.Sarvangasundara Commentary Of Aruna Datta And Ayurveda Rasayana Commentary Of Hemadri On Ashtanga Hridaya Of Acharya Vagbhata, Sutrastana Snehavidhim Adhyaya: Chapter 16 Verses 37-38.Varanasi: Chaukambha Sanskrit Sanstan:2016;

17. Bhishagacharya Pandit Hari Sadashiva Shastri Paradakara, Editor. Sarvangasundara Commentary of Aruna Datta and Ayurveda Rasayana Commentary Of Hemadri On Ashtanga Hridaya Of Acharya Vagbhata, Sutrastana Snehavidhim Adhyaya: Chapter 16 Verses 39. Varanasi: Chaukambha Sanskrit Sanstan:2016.

18. Bhishagacharya Pandit Hari Sadashiva Shastri Paradakara, Editor.Sarvangasundara Commentary Of Aruna Datta And Ayurveda Rasayana Commentary Of Hemadri On Ashtanga Hridaya Of Acharya Vagbhata, Sutrastana Ayushkameeya Adhyaya: Chapter 1 Verses

\section{Source of Support: Nil Conflict of Interest: None Declared}

How to cite this URL: Nimya K K \& Rajalaxmi M.G: A Clinical Study To Evaluate Rukshana Purvaka Virechana Karma In Sthoulya With Special Reference To Obesity. International Ayurvedic Medical Journal \{online\} 2021 \{cited September 2021\} Available from: http://www.iamj.in/posts/images/upload/3067 3075.pdf 